International Journal of

Environmental Research and

Public Health

ISSN 1660-4601

www.mdpi.com/journal/ijerph

Article

\title{
Cross-Sectional Study of Hepatitis A Virus Infection in the Pantanal Population before Vaccine Implementation in Brazil: Usage of Non-Invasive Specimen Collection
}

Renata Santos Tourinho ${ }^{1, *}$, Adilson José de Almeida ${ }^{2}$, Livia Melo Villar ${ }^{2}$, Paula Guerra Murat ${ }^{3}$, Gina Jonasson Mousquer Capelin ${ }^{3}$, Ana Rita Coimbra Motta Castro ${ }^{3}$ and

Vanessa Salete de Paula ${ }^{1}$

1 Laboratório de Desenvolvimento Tecnológico em Virologia, Instituto Oswaldo Cruz-FIOCRUZ, Cx Postal 926. Av., Brasil 4365, CEP: 21045-900 Rio de Janeiro/RJ, Brazil;

E-Mail: vdepaula@ioc.fiocruz.br

2 Laboratório de Hepatites Virais, Instituto Oswaldo Cruz-FIOCRUZ, Cx Postal 926. Av., Brasil 4365, CEP: 21045-900 Rio de Janeiro/RJ, Brazil; E-Mails: adilsonjoal@ioc.fiocruz.br (A.J.A.); lvillar@ioc.fiocruz.br (L.M.V.)

3 Departamento de Farmácia Bioquímica, Universidade Federal de Mato Grosso do Sul, Campo Grande, MS, Cx Postal 549, Brazil; E-Mails: paulamurat@hotmail.com (P.G.M.); gina.jm@hotmail.com (G.J.M.C.); arcm.castro@hotmail.com (A.R.C.M.C.)

* Author to whom correspondence should be addressed; E-Mail: renatats@ioc.fiocruz.br; Tel.: +55-21-2562-1876; Fax: +55-21-2270-6397.

Academic Editor: Paul B. Tchounwou

Received: 13 April 2015 / Accepted: 25 May 2015 / Published: 30 June 2015

\begin{abstract}
Population-based prevalence studies are essential tools for screening of hepatitis A and provide important data on susceptible groups. However, surveillance in isolated communities is difficult because of the limited access to these areas and the need for blood sample collection. This study aimed to determine the anti-HAV prevalence using oral fluid samples to provide an alternative tool for epidemiological studies that might be useful for vaccination-related decisions. The study population was composed of 224 volunteers from South Pantanal, aged 3 to 86 years old. This study was performed using oral fluids, previously standardized for anti-HAV antibody detection, which were collected using a ChemBio device. Eluates were tested using modified commercial EIA to detect anti-HAV antibodies. The overall prevalence was $79.1 \%$, corresponding to 178 reactive EIA tests out
\end{abstract}


of 224 samples. The age stratified data revealed a prevalence of $47.8 \%$ between $0-10$ years, $84 \%$ in 11-20 years and $91.9 \%$ in subjects older than 21 years. Results indicate that hepatitis A prevalence was higher in adolescents and adults, corroborating the literature reports. Thus, oral fluid samples could replace serum in HAV epidemiological studies in isolated communities as they are efficient at detecting anti-HAV antibodies.

Keywords: hepatitis A; epidemiology; oral fluid; vaccine

\section{Introduction}

Hepatitis $\mathrm{A}$ is one of the most frequently reported vaccine-preventable diseases and remains endemic in many areas of the world, especially in developing countries [1]. Hepatitis A virus (HAV) has been observed in heterogeneous pockets where susceptible or exposed individuals may co-exist. Therefore, there is a threat of a small and localized outbreak of HAV infection or even a larger outbreak in such areas [2].

The association of HAV infection with poor access to sanitation and hygiene behavior patterns, age-dependent clinical outcome of the disease, and lifelong immunity determine the different patterns of HAV infection observed around the world $[3,4]$. In areas marked by an increased prevalence rate of hepatitis $\mathrm{A}$, the infection is primarily observed among children, and most of them present with asymptomatic to self-limiting disease, generating protective immunity against hepatitis A [5]. Conversely, in areas marked by an intermediate prevalence rate for hepatitis A, a limited proportion of the adult population is reported to be immune. As a result, community-wide epidemics, resulting from person-to-person transmission may occur [5]. Finally, in areas marked by a low prevalence rate for hepatitis A, residents may be at risk for infection by travel to areas where hepatitis A is endemic and ingestion of local contaminated foods [5]. Despite the mild course of the infection during childhood, hepatitis A may cause significant morbidity and mortality among adolescents and adults [6]. Fulminant hepatitis may also develop among individuals with a predisposing underlying liver disease [7].

As a result of the epidemiological pattern transition of hepatitis A in Brazil, two distinct epidemiological patterns may be observed: the North, Northeast, and Midwest regions with intermediate endemicity of hepatitis A and the South and Southeast regions with low endemicity [8,9].This situation was highlighted in the discussion about universal mass hepatitis A vaccination program in the country. In early 2013, a vaccine against hepatitis A was incorporated into the routine children vaccination program in Brazil as a result of a cost-effective analysis to control HAV infection [5]. To determine whether the hepatitis A vaccine is effective as part of the national vaccination program, data regarding the prevalence and epidemiology of hepatitis A are essential.

In the epidemiological context, the use of oral fluids to determine HAV protection has been demonstrated to be appropriate because of its advantages and high accuracy for surveillance studies in different groups $[10,11]$. The advantages of oral specimen collection and evaluation of performance of several oral fluid collection devices in modified EIAs have led to increased interest in the use of oral fluid samples as a surrogate for serum samples. These aspects are very important, especially if we consider difficult-to-access areas where blood collection may be challenging, such as the Pantanal 
region. Pantanal is a vast wetland area, located mostly in Brazilian territory, which is of great interest for epidemiological studies [12] as its hydrography can be a source element for hepatitis A virus transmission. Nevertheless, there are no data concerning local hepatitis A virus circulation in this region. Thus, the purpose of the present study was to determine the anti-HAV prevalence using oral fluid samples to provide an alternative tool for epidemiological studies that might be useful for vaccination-related decisions.

\section{Materials and Methods}

\subsection{Ethical Aspects}

Ethical permission for collecting and testing samples was provided by the FIOCRUZ Ethical Committee (number 536/2009), and written informed consent was obtained from each participant before enrollment in the study. The specimens and questionnaires were anonymous, and feedback was provided to all participants of the study, including their hepatitis results. All unprotected participants were advised to be vaccinated against hepatitis A.

\subsection{Sample Collection and Processing}

Matched serum and oral fluid samples were collected from each participant. Five milliliters $(\mathrm{mL})$ of peripheral blood was drawn by venipuncture using hypodermic needles and multiple sterile vacuum blood collection tubes (Vacutainer system, Becton, Dickinson and Company, Franklin Lakes, NJ, USA). Subsequently, the samples were centrifuged at $1300 \mathrm{~g}$ at $25{ }^{\circ} \mathrm{C}$ for $5 \mathrm{~min}$, and the sera were stored at $-20{ }^{\circ} \mathrm{C}$. Oral fluid samples were obtained by means of a commercial device, $\mathrm{ChemBio}^{\circledR}$ (ChemBio Diagnostic Systems Inc., New York, NY, USA), which consists of a sponge swab attached to a handle with a plastic tube containing $500 \mu \mathrm{L}$ of a preservative solution. The swab was rubbed along the teeth/gum line for a minute. The collected oral fluid was concentrated at the bottom of a plastic tube after centrifugation at $1300 \mathrm{~g}$ at $25^{\circ} \mathrm{C}$ for $10 \mathrm{~min}$ and stored at $2-8{ }^{\circ} \mathrm{C}$ until analysis.

\subsection{Sample Screening}

Total anti-HAV antibodies were detected by using a commercially available, solid-phase enzyme immunoassay (EIA) based on the principle of immunocapture (ImmunoComb ${ }^{\circledR} \mathrm{II}$ HAV Ab, Orgenics, Israel). The solid phase is a comb composed of 12 projections, each one being sensitized at two positions: an upper spot with a monoclonal anti-HAV antibody (internal control) and a lower spot with rabbit anti-human $\mathrm{IgG}$ and $\operatorname{IgM}$ antibodies.

The test was performed according to the manufacturer's instructions and adapted for oral fluid samples by adding $25 \mu \mathrm{L}$ of oral fluid without sample diluents, as reported by Tourinho et al. [1]. The test results were visible as gray-blue spots on the surface of the projections, and the visual results were determined semi-quantitatively by comparing the intensity of the color of the lower spot on each projection with the color scale provided by the manufacturer. The samples results were classified according to the cut-off point (10 IU/L) of the test. A spot with an intensity greater to or equal than the cut-off point indicated the presence of protecting anti-HAV levels. A spot with an intensity slightly less than that of the cut-off was considered an equivocal result, and the sample was retested. A spot 
with a lower intensity than that of the cut-off was considered negative. The ImmunoComb ${ }^{\circledR}$ II HAV Ab assay has a limit of detection of $10 \mathrm{IU}$ anti-HAV antibodies/L, which is regarded as the minimum concentration of anti-HAV antibodies that indicates immunization has occurred. All of the samples were assayed three times, and identical visual readings for HAV were consistently observed by multiple investigators (three).

\subsection{Studied Population}

Encompassing approximately $140,000 \mathrm{~km}^{2}$ across the territories of Brazil, Bolivia, and Paraguay, the Pantanal region is one of the world's largest freshwater wetland ecosystems [12]. In Brazil, where $85 \%$ of the total area of Pantanal is located, $65.5 \%$ of the area is situated in the State of Mato Grosso do Sul (MS), and it is known as South Pantanal $[13,14]$. The region is ecologically classified into sub-regions that differ in the degree of vegetation, flooding and physiognomy [15-17] (Figure 1).

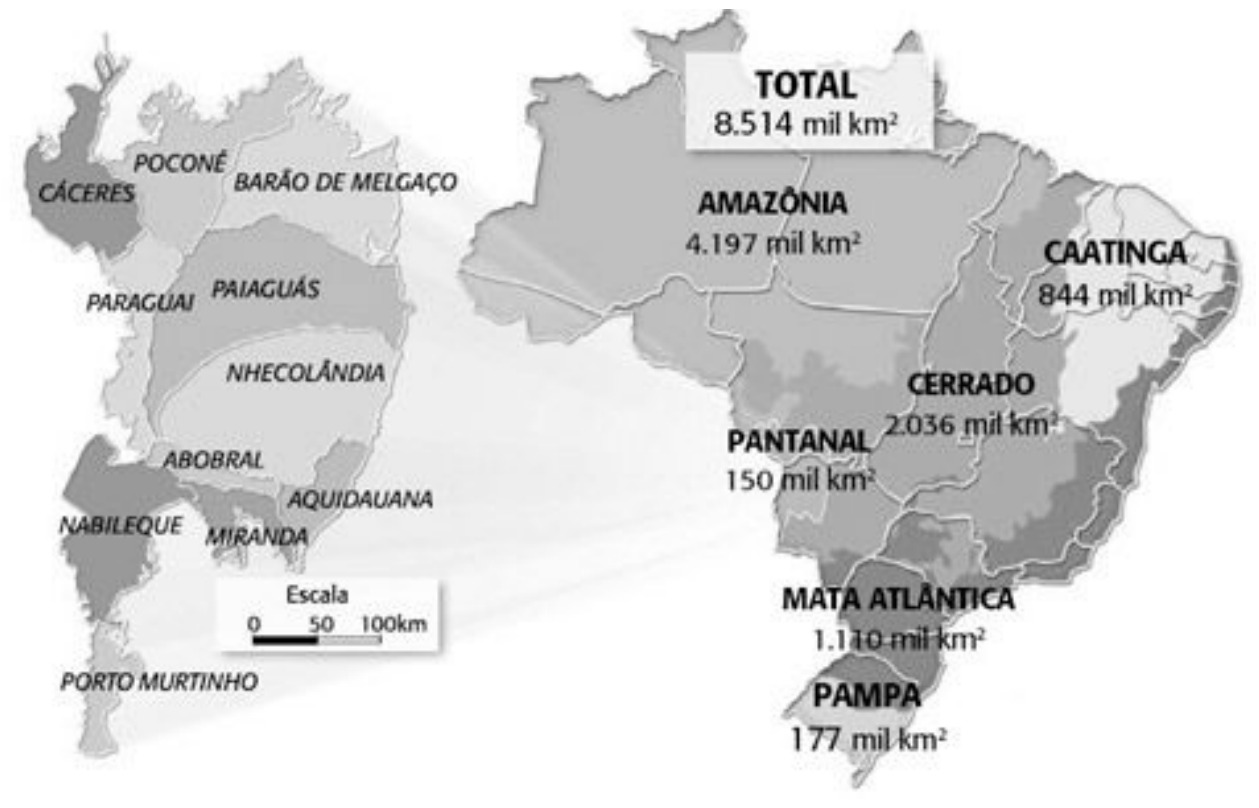

Figure 1. Sub-regions of the Brazilian Pantanal area (adapted from Globo Rural-Edition ${ }^{\odot}$ 288-October 2009).

This study was performed in four isolated communities of the Paraguay river basin sub-region, in areas that are $661 \mathrm{~km}$ far from the city of Campo Grande (MS). This region is sparsely populated, and it is characterized by wetlands that hinder access to the coastal communities; access is only available by boat. The whole population of the study area is estimated to be 691 individuals. The survey was conducted between April 2010 and June 2010, and a total of 224 paired serum and oral fluid samples were collected using a non-probability sampling method from all consenting occupants of households. The samples were placed into a cool box and returned to the laboratory after 15 days of collection for total anti-HAV screening test. The sociodemographic characteristics of each member of the study were obtained by means of questionnaires. No individual had a history of hepatitis A vaccination. 


\subsection{Statistical Analysis}

Data are presented as frequencies. The performance of the laboratory tests with the collected oral fluid samples was determined by comparing the sensitivity, specificity, and positive and negative predictive values and their respective $95 \%$ confidence intervals $(95 \% \mathrm{CI})$ with the serum results, which were used as a gold standard control. The linear and weighted kappa (k) statistic was used to evaluate the rate of agreement between the oral fluid and serum anti-HAV antibody status. According to the strength of the agreement, the $\boldsymbol{k}$ value was interpreted as follows [18]: $<20 \%$, poor; $21 \%$ to $40 \%$, fair; $41 \%$ to $60 \%$, moderate; $61 \%$ to $80 \%$, good; and $81 \%$ to $100 \%$, very good. To compare proportions, the chi-square $\left(\chi^{2}\right)$ test for independence with Yate's continuity correction, $\chi^{2}$ for trends, and Fisher's exact test (when appropriate) were used. A two-tailed $p<0.05$ was considered statistically significant. All analyses were performed with MedCalc for Windows, version 8.1.0.0 (MedCalc Software, Mariakerke, Belgium) and GraphPad InStat version 3.05 software (GraphPad Software, La Jolla, CA, USA).

\section{Results}

\subsection{Study Design and Patients}

This study was a population-based cross-sectional survey, and it was conducted in four isolated communities living in difficult-to-access areas of the Paraguay River basin, South Pantanal, Brazil: Serra do Amolar/SãoLourenço, Paraguay Mirim, Porto da Manga, and Passo do Lontra.

\subsection{Sociodemographic Characteristics of the Studied Population}

In this seroepidemiological survey, a total of 224 matched serum and oral fluid samples were obtained from volunteers, 100 (43.9\%) of which were female and $124(56.1 \%)$ male. The age of the study population ranged from 3 to 86 years, with a mean age of $26.91 \pm 17.35$ years. Because of the lack of data on anti-HAV prevalence in the studied communities, as many volunteers as possible were recruited from among the local residents (Table 1).

Table 1. Sociodemographic characteristics of the study subjects $(n=224)$.

\begin{tabular}{ccc}
\hline Variable & Studied Population (n) & Studied Population (\%) \\
\hline Age group (years) & & \\
\hline $0-10$ & 46 & $20.53 \%$ \\
$11-20$ & 50 & $22.32 \%$ \\
$21-30$ & 47 & $20.98 \%$ \\
$31-40$ & 26 & $11.61 \%$ \\
$41-50$ & 29 & $12.95 \%$ \\
$>50$ & 26 & $11.61 \%$ \\
\hline Gender & & \\
Female & 100 & $43.90 \%$ \\
Male & 124 & $56.10 \%$ \\
\hline
\end{tabular}


Table 1. Cont.

\begin{tabular}{ccc}
\hline Variable & Studied Population (n) & Studied Population (\%) \\
\hline Race/Ethnicity & & \\
\hline Caucasian & 67 & $29.91 \%$ \\
Brown & 55 & $29.00 \%$ \\
Black & 41 & $18.30 \%$ \\
Amerindian & 37 & $16.52 \%$ \\
Asian & 8 & $3.57 \%$ \\
Not reported & 6 & $2.70 \%$ \\
\hline Educational level & & \\
None & 19 & $8.48 \%$ \\
First grade & 156 & $69.60 \%$ \\
Second grade & 32 & $14.29 \%$ \\
Graduated & 14 & $6.25 \%$ \\
Not reported & 3 & $1.38 \%$ \\
\hline Family income & & \\
\hline minimun salary & 107 & $47.80 \%$ \\
2 minimun salary & 95 & $42.40 \%$ \\
3 minimun salary & 19 & $8.50 \%$ \\
Not reported & 3 & $1.30 \%$ \\
\hline Community & & \\
\hline Serra do Amolar/São Lourenço & $20.09 \%$ \\
Paraguai-Mirim & 45 & $26.78 \%$ \\
Porto da Manga & 60 & $10.27 \%$ \\
Passo do Lontra & 23 & $42.86 \%$ \\
\hline
\end{tabular}

\subsection{Anti-HAV Antibodies Detection in Serum and Oral Fluid Samples}

Total anti-HAV antibodies were detected in 181/224 serum samples by using a commercial immunoassay, ImmunoComb II HAV Ab (Orgenics), corresponding to a hepatitis A seroprevalence of $80.8 \%$. The prevalence of total anti-HAV antibodies in oral fluid was $79.01 \%$, corresponding to 177 reactive samples. Analysis of the test performance revealed the following results: sensitivity of 97.24\% (95\% CI: 0.936 to 0.991$)$, specificity of $97.67 \%$ (95\% CI: 0.877 to 0.999$)$, positive predictive value of $99.44 \%$ (95\% CI: 0.968 to 0.999 ), negative predictive value of $89.36 \%$ (95\% CI: 0.768 to 0.964 ), and Kappa coefficient of $91.7 \%$ (95\% CI: 0.851 to 0.982$)$.

\subsection{Factors Associated with Total Anti-HAV Positivity}

According to bivariate analysis, age and ethnicity were found to be statistically associated with total anti-HAV positivity in serum samples. However, only age was a factor statistically related to anti-HAV positivity in oral fluid samples (Table 2). 
Table 2. Factors associated with anti-HAV antibodies positivity in serum and oral fluid $\left(\right.$ Chembio $\left.^{\circledR}\right)$ samples from individuals living in South Pantanal, Brazil $(n=224)$.

\begin{tabular}{|c|c|c|c|c|c|c|}
\hline \multirow{2}{*}{ Variable } & \multicolumn{3}{|c|}{ Serum } & \multicolumn{3}{|c|}{ Oral Fluid $\left(\right.$ ChemBio $\left.^{\circledR}\right)$} \\
\hline & Positive $(n=181)$ & Negative $(n=43)$ & $p$ & Positive $(n=177)$ & Negative $(n=47)$ & $p$ \\
\hline $\begin{array}{c}\text { Age (years), median } \\
\text { (interval) }\end{array}$ & $27(5.0-86.0)$ & $10(3.0-72.0)$ & $<0.0001$ & $26(5.0-86.0)$ & $11(3.0-77.0)$ & $<0.0001$ \\
\hline Gender, $n(\%)$ & & & 0.9175 & & & 0.9953 \\
\hline Male & $101(55.8)$ & $23(53.4)$ & & $98(53.3)$ & $26(55.3)$ & \\
\hline Female & $80(44.2)$ & $20(46.6)$ & & $79(46.7)$ & $21(44.7)$ & \\
\hline Race/Ethnicity, n (\%) & & & 0.0312 & & & 0.2797 \\
\hline Caucasian & $33(18.2)$ & $14(32.6)$ & & $51(28.8)$ & $16(34.0)$ & \\
\hline Brown & $58(32.0)$ & $7(16.3)$ & & $57(32.2)$ & $8(17.0)$ & \\
\hline Black & $53(29.3)$ & $8(18.6)$ & & $32(18.1)$ & $9(19.3)$ & \\
\hline Amerindian & $26(14.4)$ & $11(25.6)$ & & $26(14.7)$ & $11(23.4)$ & \\
\hline Asian & $6(3.3)$ & $2(4.6)$ & & $6(6.4)$ & $2(4.2)$ & \\
\hline $\mathrm{NR}^{\mathrm{a}}$ & $5(2.8)$ & $1(2.3)$ & & $5(2.8)$ & $1(2.1)$ & \\
\hline \multicolumn{2}{|c|}{ Domestic residents, $n$ (\%) } & & 0.1589 & & & 0.7919 \\
\hline $0-1$ & $17(9.4)$ & $5(11.6)$ & & $16(9.0)$ & $6(12.8)$ & \\
\hline $2-3$ & $56(30.9)$ & $4(9.3)$ & & $53(29.9)$ & $7(14.9)$ & \\
\hline $4-5$ & $41(22.7)$ & $14(32.6)$ & & $40(22.6)$ & $15(31.9)$ & \\
\hline $6-7$ & $33(18.2)$ & $9(20.9)$ & & $32(18.1)$ & $10(21.3)$ & \\
\hline$>7$ & $33(18.2)$ & $10(23.3)$ & & $35(19.8)$ & $8(17.0)$ & \\
\hline NR & $1(0.6)$ & $1(2.3)$ & & $1(0.6)$ & $1(2.1)$ & \\
\hline \multicolumn{2}{|c|}{ Educational level, $n$ (\%) } & & 0.8396 & & & 0.7248 \\
\hline None & $14(7.7)$ & $5(11.6)$ & & $14(7.9)$ & $5(10.7)$ & \\
\hline First grade & $127(70.2)$ & $29(67.5)$ & & $126(71.2)$ & $30(63.8)$ & \\
\hline Second grade & $28(15.5)$ & $4(9.3)$ & & $25(14.1)$ & $7(14.9)$ & \\
\hline Graduated & $10(5.5)$ & $4(9.3)$ & & $10(5.6)$ & $4(8.5)$ & \\
\hline NR & $2(1.1)$ & $1(2.3)$ & & $2(1.2)$ & $1(2.1)$ & \\
\hline \multicolumn{3}{|c|}{ Familiar income (minimum salary), $n$ (\%) } & 0.7331 & & & 0.8599 \\
\hline$\leq 1$ & $82(45.3)$ & $25(58.1)$ & & $81(45.7)$ & $26(55.3)$ & \\
\hline 2 & $85(47.0)$ & $10(23.3)$ & & $82(46.3)$ & $13(27.7)$ & \\
\hline 3 & $12(6.6)$ & $7(16.3)$ & & $12(6.8)$ & $7(14.9)$ & \\
\hline NR & $2(1.1)$ & $1(2.3)$ & & $2(1.2)$ & $1(2.1)$ & \\
\hline \multicolumn{3}{|c|}{ Drinking water (source), $n$ (\%) } & 0.2302 & & & 0.4174 \\
\hline Untreated (river) & $56(30.9)$ & $11(25.6)$ & & $56(31.6)$ & $11(23.4)$ & \\
\hline Treated (river) ${ }^{\mathbf{b}}$ & $107(59.2)$ & $30(69.8)$ & & $104(58.6)$ & $33(70.2)$ & \\
\hline $\begin{array}{l}\text { Bottled (mineral } \\
\text { water) }\end{array}$ & $16(8.8)$ & $1(2.3)$ & & $5(2.8)$ & $2(4.2)$ & \\
\hline NR & $2(1.1)$ & $1(2.3)$ & & $2(1.2)$ & $2(4.2)$ & \\
\hline \multicolumn{3}{|c|}{ History of hepatitis A, n (\%) } & 0.0903 & & & 0.2506 \\
\hline No & $161(89.0)$ & $42(97.7)$ & & $159(89.8)$ & $44(93.7)$ & \\
\hline Yes & $16(8.8)$ & $0(0.0)$ & & $15(8.5)$ & $1(2.1)$ & \\
\hline NR & $4(2.2)$ & $1(2.3)$ & & $3(1.7)$ & $2(4.2)$ & \\
\hline
\end{tabular}


Table 2. Cont.

\begin{tabular}{|c|c|c|c|c|c|c|}
\hline \multirow{2}{*}{ Variable } & \multicolumn{3}{|c|}{ Serum } & \multicolumn{3}{|c|}{ Oral Fluid (ChemBio $\left.{ }^{\circledR}\right)$} \\
\hline & Positive $(n=181)$ & Negative $(n=43)$ & $p$ & Positive $(n=177)$ & Negative $(n=47)$ & $p$ \\
\hline Community, $n$ (\%) & & & 0.0562 & & & 0.1157 \\
\hline Passo do Lontra & $81(44.8)$ & $15(34.2)$ & & $77(43.5)$ & $19(40.4)$ & \\
\hline Porto da Manga & $22(12.2)$ & $1(2.3)$ & & $22(12.4)$ & $1(2.1)$ & \\
\hline Paraguai-Mirim & $43(23.7)$ & $17(39.5)$ & & $43(24.3)$ & $17(36.2)$ & \\
\hline \multicolumn{7}{|l|}{ Serra do } \\
\hline Amolar/São & $35(19.3)$ & $10(23.3)$ & & $35(19.7)$ & $10(21.3)$ & \\
\hline Lourenço & & & & & & \\
\hline
\end{tabular}

${ }^{\text {a }}$ Not Reported; ${ }^{\mathbf{b}}$ including treated water by chlorination, filtration and boiling.

The seroprevalence of HAV infection ranged from $70.2 \%$ in Caucasian individuals to $89.2 \%$ in brown subjects. The positivity for these antibodies in serum was higher in brown and black and subjects, $89.2 \%$ and $86.9 \%$, respectively, compared with the other ethnicities of the study.

The proportions of anti-HAV positivity were considered to be similar in both types of biological samples by age group, with a maximum difference of $7.7 \%$ in the age group of $31-40$ years old. The seroprevalence progressively increased from $50 \%$ in children $0-10$ years up to $100 \%$ among individuals aged 31-40 years. A similar trend was observed for oral fluid samples, where disease prevalence ranged from $50 \%$ in children $0-10$ years to $93.10 \%$ among individuals who were 41-50 years old. There was a significant increase in prevalence, approximately $40 \%$, between the ages of 0-10 and 11-20 years of age, for both types of clinical specimens (Figure 2).

A difference in the anti-HAV positivity rate among the communities studied, which ranged from $71.67 \%$ (43/60) in the community of Paraguay-Mirim to 95.65\% (22/23) in Porto da Manga, was also observed. The prevalence of HAV infection was higher in communities closer to urban centers, such as Passo do Lontra (84.38\%) and Porto da Manga (95.65\%), than in most remote and difficult-to-access communities, such as Paraguay-Mirim (71.67\%) and Serra do Amolar/São Lourenço (77.78\%) (Figure 3). Despite this variability, anti-HAV positivity was not significantly associated with a particular community.

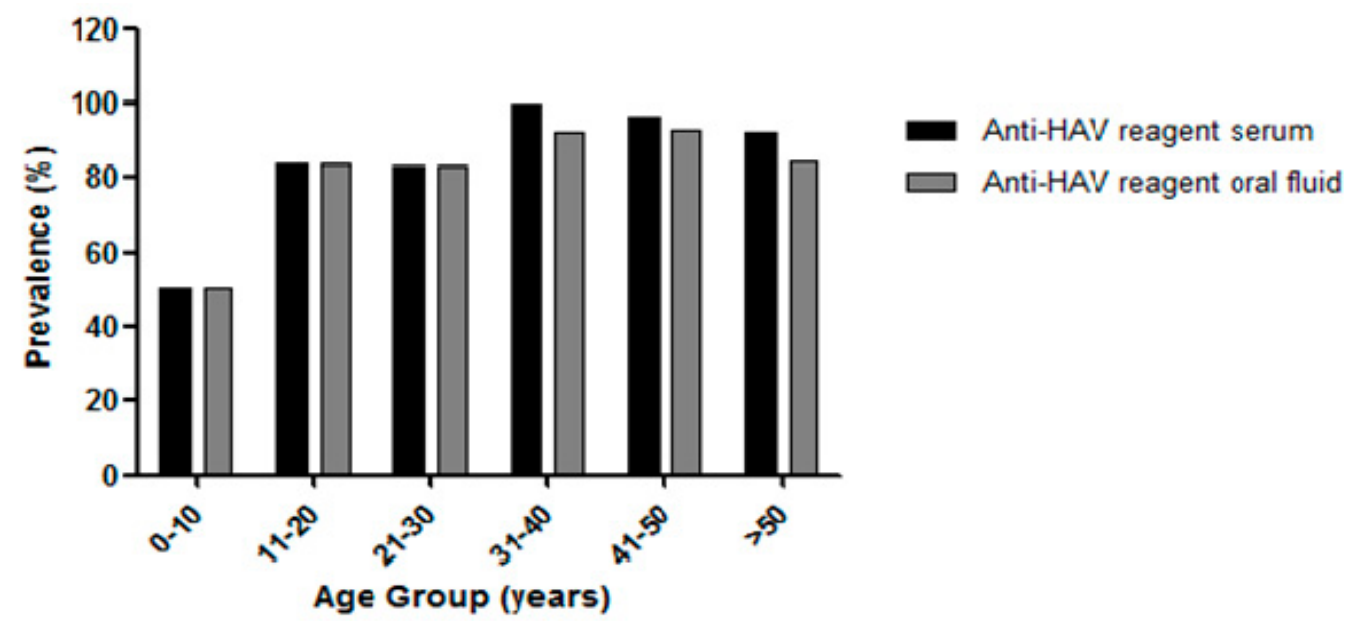

Figure 2. Total anti-HAV prevalence in serum and oral fluid by age group from individuals linving in difficul-to-access areas of South Pantanal, Brazil. 


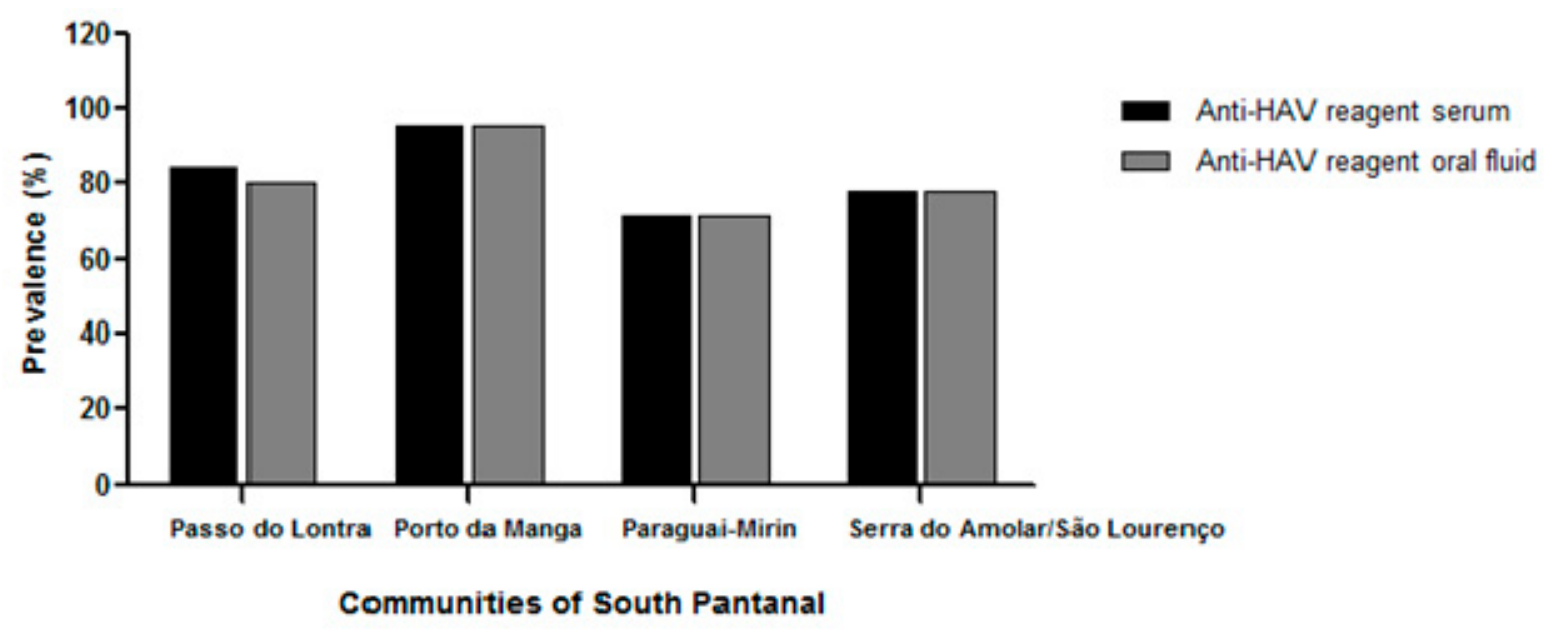

Figure 3. Total anti-HAV prevalence in serum and oral fluid by communites from individuals linving in difficul-to-access areas of South Pantanal, Brazil.

\section{Discussion}

In Brazil, HAV infection accounts for the majority of viral hepatitis notifications. Changes in the epidemiological patterns have been described in some regions due to improvements in sanitation and socioeconomic conditions. Nevertheless, all three patterns can be identified even within a particular geographical region [8]. HAV infection has an intermediate prevalence in Brazil, and it is considered endemic to the country [19].

The issue of implementing a national vaccination program against hepatitis $\mathrm{A}$ in Brazil has been widely discussed in view of the difficulty of establishing a unified project in an area of continental dimensions and macro-regions with distinct epidemiological profile of the disease. In Brazil, HAV available vaccine is imported, and it has been recently evaluated for inclusion in the childhood vaccination schedule. For determination of national policies on vaccination, the results of epidemiological studies and cost-benefit must be carefully considered and the impact on public health must be balanced [2,20].

For epidemiological monitoring purposes, the use of oral fluid samples is of great importance because, as shown by different authors [21-26] this specimen type has many clinical advantages and appears to be accurate enough to be used in such situations. However, many of these studies have proposed the use of oral fluid as an alternative tool for blood samples. If the benefits of such clinical specimen have been demonstrated, and its efficiency in enzyme immunoassays has sometimes proven, why not use it as a substitute for blood collection?

As demonstrated in this study, oral fluid samples may, in fact, serve as a substitute for blood collection. However, it is important to select the most appropriate device for sample collection and field studies [1,27], providing accurate information to determine the epidemiological profile, the need for immunization and disease control strategies [28].

To determine the efficiency oral fluid samples and its applicability in field research as a substitute for serum, the first investigation of HAV infection in difficult-to-access communities was held in the South Pantanal. Using samples collected from different individuals belonging to these communities, we observed a close relationship between the HAV prevalence in oral fluid samples collected with 
ChemBio $^{\circledR}$ (79.01\%) device and HAV seroprevalence $(81.25 \%)$. The agreement between the results of oral fluid and the "gold standard" (serum) was 97.32\% (sensitivity $=97.24 \%$ and specificity $=97.67 \%$ ).

A high overall anti-HAV prevalence rate $(81.25 \%)$ was found compared with that observed in the general population (55.7\%) in the South and Southeast regions of Brazil. However, this rate was lower than the rate found in the North $(92.8 \%)$ and more similar to the rate obtained in the Northeastern region of Brazil (76.5\%) [29].

Although some studies have demonstrated that urban populations have lower rates of HAV infection than rural populations [30-32], in this study, communities closer to urban centers had a higher rate of HAV exposure than the rate observed among individuals from the rural areas $(91.65 \%$ and $84.38 \%$ versus $71.67 \%$ and $77.78 \%$, respectively). Similarly, Almeida and colleagues [33] found a higher HAV prevalence in urban areas $(87.4 \%)$ compared with rural settlement areas of Cavunge (79.7\%), a semiarid region of Bahia state in Northeast Brazil.

Furthermore, in the present investigation, people living in these communities reported having a low income. Despite the fact that anti-HAV positivity was not significantly associated with water source, the inhabitants of these rural areas do not have adequate facilities for sanitation and use river water for washing and consumption as well as for their personal hygiene. Urban communities are located near the hotel industry and farms, where poor sanitation conditions persist, and environmental sanitation projects either do not exist or are still under construction. Apart from sanitation facilities and hygiene conditions, the residents' houses are located close to each other, and the high population density in low-income urban communities can contribute to the spread of the hepatitis A virus.

The anti-HAV seroprevalence was significantly associated with age. Stratification by age revealed that although the overall prevalence was $81.25 \%$, only $50 \%$ of children aged $0-10$ years are immune to the disease. This rate is higher than that observed by De Alencar Ximenes and colleagues [8] in the capitals of the Northeast and Midwest regions of Brazil, 32\% and 34\%, respectively. However, the prevalence is lower (60\%) than in individuals younger than 10 years in the Amazon region [34]. Data from these studies demonstrate a low prevalence in this age group in these regions.

Despite the prevalence of HAV infection having been linked to race/ethnicity, this association appears more to reflect a regional characteristic.

The combination of the collection and preservation of samples with the stabilizers in ChemBio ${ }^{\circledR}$ device methodology is considered as an important strategy to avoid problems of rapid degradation during antibody storage, as reported by Gröschl and colleagues [35] for other collectors.

\section{Conclusions}

The use of oral fluid specimens is a helpful tool for understanding the hepatitis A prevalence in areas where no data are available and might be useful for vaccination-related decisions since it is efficient in detecting susceptible individuals.

\section{Acknowledgments}

The authors thank the Fundação de Amparo à Pesquisa do Estado do Rio de Janeiro (FAPERJ) and the Oswaldo Cruz Foundation (FIOCRUZ) for the financial support. 


\section{Author Contributions}

Renata Santos Tourinho carried out the epidemiological study, performed the immunoassays and drafted the manuscript. Adilson José de Almeida participated in the design of the study and performed the statistical analysis. Livia Melo Villar carried out and coordinated the epidemiological study in the community of Passo do Lontra. Paula Guerra Murat and Gina Jonasson Mousquer Capelin carried out and coordinated the epidemiological study in the community of Porto da Manga. Ana Rita Coimbra Motta Castro carried out and coordinated the epidemiological study in the communities of Paraguai-Mirim and Serra do Amolar/São Lourenço. Vanessa Salete de Paula conceived the study, and participated in its design and coordination and helped to draft the manuscript. All authors read and approved the final manuscript.

\section{Conflicts of Interest}

The authors disclose no actual or potential conflicts of interest, including any financial, personal or other relationships with people or organizations within two years of the beginning of this study that could inappropriately influence the study.

\section{References}

1. Tourinho, R.S.; de Almeida, A.J.; Amado, L.A.; Villar, L.M.; Castro, A.R.; de Paula, V.S. Could oral fluid be used to evaluate anti-hepatitis A virus status in individuals living in difficult-to-access areas? Vaccine 2012, 30, 6421-6426.

2. Sartori, A.M.; de Soárez, P.C.; Novaes, H.M.; Amaku, M.; de Azevedo, R.S.; Moreira, R.C.; Pereira, L.M.; Ximenes, R.A.; Martelli, C.M. Cost-effectiveness analysis of universal childhood hepatitis A vaccination in Brazil: Regional analyses according to the endemic context. Vaccine 2012, 30, 7489-7497.

3. Jeong, S.H.; Lee, H.S. Hepatitis A: Clinical manifestations and management. Intervirology 2010, $53,15-19$.

4. Matheny, S.C.; Kingery, J.E. Hepatitis A. Am. Fam. Phys. 2012, 86, 1027-1034.

5. Shapiro, C.N.; Margolis, H.S. Worldwide epidemiology of hepatitis A virus infection. J. Hepatol. 1993, 18, S11-S14.

6. Mackinney-Novelo, I.; Barahona-Garrido, J.; Castillo-Albarran, F.; Santiago-Hernández, J.J.; Méndez-Sánchez, N.; Uribe, M.; Chávez-Tapia, N. Clinical course and management of acute hepatitis A infection in adults. Ann. Hepatol. 2012, 11, 652-657.

7. Jayakumar, S.; Chowdhury, R.; Ye, C.; Karvellas, C.J. Fulminant viral hepatitis. Crit. Care Clin. 2013, 29, 677-697.

8. De Alencar Ximenes, R.A.; Martelli, C.M.; Merchán-Hamann, E.; Montarroyos, U.R.; Braga, M.C.; de Lima, M.L.; Cardoso, M.R.; Turchi, M.D.; Costa, M.A.; de Alencar, L.C.; et al. Hepatitis Study Group. Multilevel analysis of hepatitis A infection in children and adolescents: A household survey in the Northeast and Central-west regions of Brazil. Int. J. Epidemiol. 2008, 37, 852-861. 
9. Ximenes, R.A.; Pereira, L.M.; Martelli, C.M.; Merchán-Hamann, E.; Stein, A.T.; Figueiredo, G.M.; Braga, M.C.; Montarroyos, U.R.; Brasil, L.M.; Turchi, M.D.; et al. Methodology of a nationwide cross-sectional survey of prevalence and epidemiological patterns of hepatitis A, B and C infection in Brazil. Cad. Saude Pública 2010, 26, 1693-1704.

10. Parry, J.V. Detection of viral antibodies in saliva specimens as an alternative to serum. Diagnosis of hepatitis A and B by testing saliva. J. Clin. Chem. Clin. Biochem. 1989, 27, 245-246.

11. Morris-Cunnington, M.C.; Edmunds, W.J.; Miller, E.; Brown, D.W.G. A population-based seroprevalence study of hepatitis A virus using oral fluid in England and Wales. Am. J. Epidemiol. 2004, 159, 786-794.

12. Lopes, M.H. Prevenção da hepatite B e delta. Braz. J. Infect. Dis. 2006, 10, S72-S78. (In Portuguese)

13. Alho, C.J.R.; Lacher, T.E., Jr.; Gonçalves, H.C. Environmental degradation in the Pantanal ecosystem. BioScience 1988, 38, 164-171.

14. Moraes, A.S.; Resende, E.K.; Rodrigues, C.A.G.; Mauro, R.A.; Galdino, S.; Oliveira, M.D.; Crispim, S.M.A.; Vieira, L.M.; Soriano, B.M.A.; Abreu, U.G.P.; et al. Embrapa Pantanal: 25 anos de pesquisas em prol da conservação do Pantanal, os desafios do novo milênio. In III Simpósio Sobre Recursos Naturais e Sócio-Econômicos do Pantanal: O Desafio do novo Milênio; Embrapa Pantanal: Corumbá, Brazil, 2001; p. 55. (In Portuguese)

15. Adámoli, J. Fisiografia do Pantanal. In Recursos Forrageiros Nativos do Pantanal Mato-Grossense; Allem, A.C., Valls, J.F.M., Eds.; Documento 8, Embrapa Cenargen: Brasília, Brazil, 1987; pp. 15-22.

16. Silva, J.V.; Abdon, M.M. Delimitação do Pantanal brasileiro e suas sub-regiões. Pesqui. Agropecu. Bras. 1998, 33, 1703-1711. (In Portuguese)

17. Magalhães, N.W. O Pantanal: Aspectos gerais. In Conheça o Pantanal, 1st ed.; Cap 1, Terragraph: São Paulo, Brazil, 1992; pp. 7-12.

18. Altman, D.G. Practical Statistics for Medical Research; Chapman and Hall: London, UK, 1991.

19. Fiore, A.E.; Wasley, A.; Bell, B.P. Prevention of hepatitis A through active or passive immunization: Recommendations of the Advisory Committee on Immunization Practices (ACIP). Morb. Mortal. Wkly. Rep. Recomm. Rep. 2006, 55, 1-23.

20. FitzSimons, D.; Hendrickx, G.; Vorsters, A.; van Damme, P. Hepatitis A and E: Update on prevention and epidemiology. Vaccine 2010, 28, 583-588.

21. Parry, J.V. Simple and reliable salivary test for HIV and hepatitis A and B virus diagnosis and surveillance. Ann. N.Y. Acad. Sci. 1993, 694, 216-233.

22. McIntyre, P.G.; Laszlo, J.; Appleyard, K.; Ogden, G.R. Modified enzyme immunoassay to detect hepatitis C virus antibodies in oral fluid. Eur. J. Microbiol. Infect. Dis. 1996, 15, 882-884.

23. Ochnio, J.J.; Scheifele, D.H.; Ho, M.; Mitchell, L.A. New, ultrasensitive enzyme immunoassay for detecting vaccineand disease-induced hepatitis A virus-specific immunoglobulin $\mathrm{G}$ in saliva. J. Clin. Microbiol. 1997, 35, 98-101.

24. Oba, I.T.; Spina, A.M.M.; Saraceni, C.P.; Lemos, M.F.; Senhoras, R.C.F.A.; Moreira, R.C.; Granato, C.F.H. Detection of hepatitis A antibodies by ELISA using saliva as clinical samples. Rev. Med. Trop. São Paulo 2000, 42, 197-200. 
25. Chohan, B.H.; Lavreys, L.; Mandaliya, K.N.; Kreiss, J.K.; Bwayo, J.J.; Ndinya-Achola, J.O.; Martin, H.L., Jr. Validation of a modified commercial enzyme-linked immunoassay for detection of human immunodeficiency virus type 1 immunoglobulin $\mathrm{G}$ antibodies in saliva. Clin. Diagn. Lab. Immunol. 2001, 8, 346-348.

26. Amado, L.A.; Villar, L.M.; de Paula, V.S.; de Almeida, A.J.; Gaspar, A.M.C. Detection of hepatitis $\mathrm{A}, \mathrm{B}$ and $\mathrm{C}$ virus-specific antibodies using oral fluid for epidemiological studies. Mem. Inst. Oswaldo Cruz 2006, 101, 149-155.

27. Chang, C.K.; Cohen, M.E.; Bienek, D.R. Efficiency of oral fluid collection devices in extracting antibodies. Oral Microbiol. Immunol. 2009, 24, 231-235.

28. Robertson, S.E.; Cutts, F.T.; Samuel, R.; Diaz-Ortega, J.L. Control of rubella and congenital rubella syndrome (CRS) in developing countries: A global review, Part II, Vaccination against Rubella. Bull. World Health Organ. 1997, 75, 69-80.

29. Clemens, S.A.; Da Fonseca, J.C.; Azevedo, T.; Cavalcanti, A.; Silveira, T.R.; Castilho, M.C.; Clemens, R. Hepatitis A and hepatitis B seroprevalence in 4 centers in Brazil. Rev. Soc. Bras. Med. Trop. 2000, 33, 1-10.

30. Barzaga, N.G. Hepatitis A shifting epidemiology in South-East Asia and China. Vaccine 2000, 18, S61-S64.

31. Tufenkeji, H. Hepatitis A shifting epidemiology in the Middle East and Africa. Vaccine 2000, 18, S65-S67.

32. Arankalle, V.A.; Chadha, M.S. Who should receive hepatitis A vaccine? J. Viral Hepat. 2003, 10, 157-158.

33. Almeida, D.; Tavares-Neto, J.; Queiroz-Andrade, M.; Dias, C.; Ribeiro, T.; Silva, F.; Silva-Araújo, J.; Tatsch, F.; Paraná, R. Sociodemographical aspects of seroprevalence of hepatitis A virus in the settlement of Cavunge, a semi-arid region of Bahia State. Rev. Soc. Bras. Med. Trop. 2006, 39, 76-78.

34. Braga, W.S.; Borges, F.G.; Barros Junior, G.M.; Martinho, A.C.; Rodrigues, I.S.; Azevedo, E.P.; Davis, G.H.; Queiroz, M.B.; Santos, S.H.; Barbosa, T.V.; et al. Prevalence of hepatitis A virus infection: The paradoxical example of isolated communities in the western Brazilian Amazon region. Rev. Soc. Bras. Med. Trop. 2009, 42, 277-281.

35. Gröschl, M.; Köhler, H.; Topf, H.G.; Rupprecht, T.; Rauh, M. Evaluation of saliva collection devices for the analysis of steroids, peptides and therapeutic drugs. J. Pharm. Biomed. Anal. 2008, $47,478-486$.

(C) 2015 by the authors; licensee MDPI, Basel, Switzerland. This article is an open access article distributed under the terms and conditions of the Creative Commons Attribution license (http://creativecommons.org/licenses/by/4.0/). 